\title{
Comparative Study Between Gender Bias in Household Water Conservation and Management in Commune of Pelengana
}

\author{
Hawa Diakite $^{1} \quad$ Yujuan Gao $^{1^{*}} \quad$ Amadou Toure ${ }^{2}$ \\ 1.College of Economics and Management, Northeast Forestry University, No.26 Hexing Road Xiangfang \\ District, Harbin 150040, China \\ 2.School of Forestry, Northeast Forestry University, No.26 Hexing Road Xiangfang District, Harbin 150040, \\ China
}

\begin{abstract}
Highlighting the practice of water conservation (PWC) is a safe way to accomplish water savings. Nevertheless, parameters affecting behavior change linked to water use keep uncertain. In this study, 467 residents (female: 272; male: 195) from three villages situated in the commune of Pelengana in Segou, Mali were investigated in order to analyze the effects of awareness, perceptions and individual water-use patterns control on PWC, and also the influence of gender on inhabitants' PWC. One-way analysis of variance (ANOVA) followed by post-hoc LSD tests were used in analyzing different data. Participants were very familiar with PWC, but stated low involvement in PWC, especially among men consumers. Although women adopted more PWC than men, the amount of water consumed by these women was more twice greater that of men. Women consumers engaged in PWC principally to reduce water costs, while men consumers applied PWC principally for water scarcity reduction. Daily habits changes and demands of extra time and effort were the principal obstacles for PWC, notably for men consumers. In all, there is a pressing need to enhance information clarity and communication among gender, consumers, and decision-makers to strengthen social assistance for water conservation.
\end{abstract}

Keywords: Water conservation, behavior, gender, awareness, water-use patterns, Mali's rural area

DOI: $10.7176 / \mathrm{JRDM} / 63-05$

Publication date:March $31^{\text {st }} 2020$

\section{Introduction}

Water destined for human consumption, and domestic uses are essential to maintaining a public health and it contributes to the quality of life of households through the provision of basic needs of water and sanitation. However, in low-income nations, particularly in rural areas, water distribution is consistently low, since high water quality is necessary and considerable investments generally required for equipment. Some noteworthy statistics from the WHO/UNICEF Joint Monitoring Program 2017 (JMP) for Water and Sanitation reveal that in such areas, roughly 748 million people do not have access to sufficient safe drinking water. Additionally, 2.4 billion human beings lack access to improve sanitation conditions (WHO \& UNICEF 2017). Governments, the World Health Organization (WHO) and several other development partners have tried to extend water distribution systems in order to ensure potable water supply in low-income countries. Thanks to their attempts, more than 2.6 billion human beings were able to access safe drinking water between 1995 and 2015. Nowadays, more than $90 \%$ of the world's population has access to potable water (WHO \& UNICEF 2017). In Mali, hundreds million dollars has been invested in water distribution systems from 2005 to 2013 , and roughly 1,700 modern water points have been built for $62 \%$ of the overall rural inhabitants by the end of 2013 (UN-WATER/WWAP 2016).

As noted by Coulibaly. (2009), water consumption for domestic use increased in households that have recently accessed improved water supplies. The consumption then goes from 4 liters per day and per capita to 10 liters in the rural areas of Mali (WHO/UNICEF Joint Monitoring Program. 2015). In rural Cameroon, inhabitants used 5 liters per day and per capita prior and 15 liters per day and per capita after the installation of community taps (Tyler et al., 2017). Designed water supply capacity frequently does not respond the growing request for water. This is an obstacle to the supply of potable water in rural zones even after receiving improved water supply (Jessica et al., 2014). As a result, restrictive policies such as irregular water supply and rising water prices are extensively performed at the rural levels. However, several studies have criticized these approaches for their non-equitable effects, health risks, and capacity to bring about water panic (Kumpel \& Nelson 2013).

As increasing water distribution capacity is strongly affected by economic, environmental, and water resource constraints, governments, partners of development (NGOs), and scientists have been working together to find ways to reduce request from inhabitants (Programme 2012). Some measures were suggested to implement significant water savings. Some of the most effective measures include information action to the inhabitants, or more precisely "an awareness". It is going to be to change the behaviors, monitor its water bill, or water station's collective charges when billing is not direct, know its consumption and track its evolution to detect possible anomalies (monitor its meter), compare it to known averages, search for causes of discrepancy, check the condition of its facilities (gaskets, flushing) in case of aberrant consumption (Shove et al., 2010). It's worth noting that in Australian, domestic water use has been decreased by a mean of $19 \%$ from 2001 to 2004 thanks to information actions and request 
management (Yan \& Liangxin 2017). According to Shove et al. (2010), domestic water use is projected to fall by $13.3 \%$ in England in 2030 owing water use attitude change. As a result, reducing water waste through behavior is not easy. Inhabitants may be reticent to change their manners owing to their personal characteristics, awareness, practices and even gender discrepancy (Yan \& Liangxin 2017).

In rural areas, especially in low-income countries, it has been proved that women and girls are the principal stakeholders in the quotidian activities of households, namely collect and transport of water, cooking, laundry, washing, and hygiene (Garcetti \& Kevany 2013). As a result, women are generally not considered equal to men in their involvement in water governance due to gender discrimination, ignorance, tradition and culture restrictions (Caruso et al., 2015). However, women's opinions and feelings, and also gender disparity in use and conservation behaviors, are systematically disregarded in collective policies (Liangxin et al., 2014). Such negligence leads to ineffective management of water resources (Garcetti \& Kevany 2013).

The aims of our study are as follows: (1) to quantize and classify the difference in cognizance, perceptions and behavior regarding domestic water use with respect to gender (i.e. between males and females) in rural zones of Pelengana commune in Segou, Mali, (2) to identify the main factors of disparity between males and females in residents' water use behavior, and (3) to examine and recommend public policies to orientate inhabitants in adopting water saving practices.

\section{Materials and Methods}

\subsection{Description of the study area}

Our research was conducted in the rural commune of Pelengana in Segou region. The region is located in the center of Mali between $12^{\circ} 30^{\prime}$ and $15^{\circ} 30^{\prime} \mathrm{N}$ latitude and $4^{\circ}$ and $7^{\circ} \mathrm{W}$ longitude, with a total area of $62504 \mathrm{~km}^{2}$ and a population of 2338349 based on the 2009 census (RGPH 2009). Currently, the commune of Pelengana has more than 10500 displaced people. They are settled in villages inside the commune, and these villages are reported in (Figure.1). Segou region has a sudano-sahelian climate with two seasons, dry season that lasts eight months (October-May), and rainy season that lasts four months (June-September). Rainfall of the region ranges from 200 to $800 \mathrm{~mm}$ per year and the average annual temperature is $28^{\circ} \mathrm{C}$. Agriculture, livestock and fishing are the main activities of the region (OWAS 2007).

Guarantee clean water supply for quotidian use by rural inhabitants is the principal problem faced by the Ministry of Health in Mali. Highly polluted surface water makes the situation worked, roughly $95 \%$ of the water supply for domestic use is sourced from boreholes water (i.e. from underground water) (Amadou Toure 2018). However, designed water distribution system has therefore been unable to meet the increased request for water consumption. Consequently, $43 \%$ of the villages receiving borehole water had to switch to intermittent water supplies to limit water use.

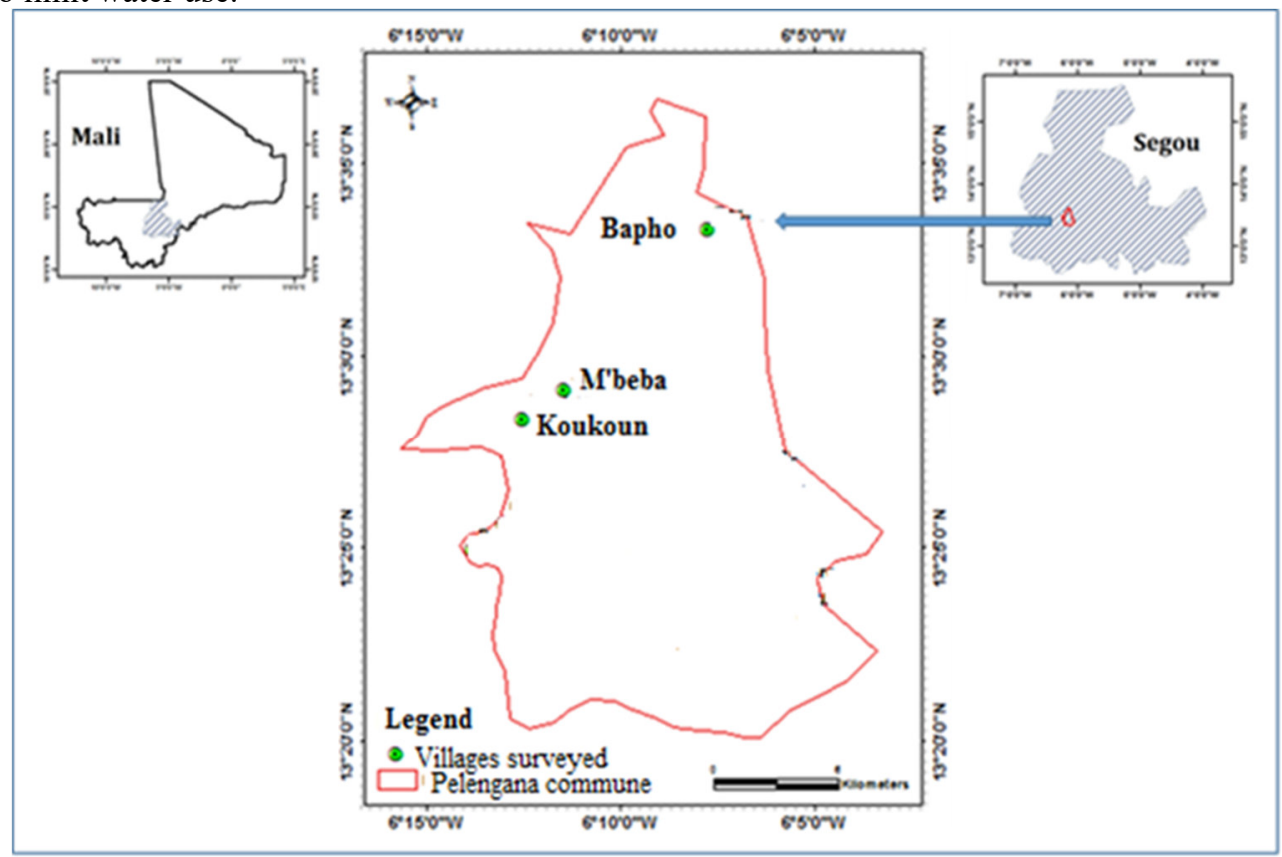

Figure 1. Map of the study zone in Mali

\subsection{Survey design and data collection}

The questionnaire survey was carried out through face-to-face interviews throughout 5 months, from January to 
May 2018. 160 randomly selected households per village were used for the interview. A total of 480 households (i.e. 480 residents including 280 females and 200 males) living in the village of Koukoun (female: 93; male: 67), M'beba (female: 85; male: 75), and Bapho (female: 102; male: 58) in the commune of Pelengana. These 3 villages situated in Pelengana commune possess similar climate and socio-economic characteristics. Owing to the lowest level of literacy rates in the study area, informed consent was verbally getting before beginning with each interview and documented through the full completion of the survey. Identification codes have been assigned to each house and to each household member for reasons of anonymous conservation. Participants were informed that they were entirely free to stop the investigation at any time, for any reason and without providing justification. 13 incomplete questionnaires and 467 complete questionnaires including 272 females and 195 males have been recorded (Table 1).

Questions in the survey included household demographic information (age, educational status, household income, and household size), attitudes to water conservation (AWC), individual water-use patterns (perception of ease or difficulty in achieving water conservation) (WUP), expected outcomes (water-efficient practices, water scarcity reduction and environmental protection) (EO), social standards (public perception and decision-makers' attitudes with regard to water conservation) (SS), and practices of water conservation (PWC) (Table 2). Likert scale has been used to quantify questionnaire responses. The responses were on a 5 point scale, with gradations: $1=$ not probable, $2=$ Somewhat improbable, $3=$ neither improbable nor probable, $4=$ probable, $5=$ Very probable. Noted that, higher scores designated a greater probability.

Table 1. Demographic characteristics of the participants.

\begin{tabular}{|l|l|l|l|l|l|}
\hline Villages & $\begin{array}{l}\text { Number of } \\
\text { household } \\
\text { surveyed }\end{array}$ & $\begin{array}{l}\text { Household } \\
\text { size }\end{array}$ & $\begin{array}{l}\text { Annual household } \\
\text { income (USD) }\end{array}$ & $\begin{array}{l}\text { Models of } \\
\text { water supply }\end{array}$ & $\begin{array}{l}\text { Unit price of water } \\
\text { (USD/m3) }\end{array}$ \\
\hline Koukoun & 156 & 5.4 & 1576 & $\begin{array}{l}\text { 24-hour piped } \\
\text { water supply }\end{array}$ & 0.15 \\
\hline M'beba & 158 & 5.2 & 1518 & $\begin{array}{l}\text { 24-hour piped } \\
\text { water supply }\end{array}$ & 0.15 \\
\hline Bapho & 153 & 5 & 1460 & $\begin{array}{l}\text { 24-hour piped } \\
\text { water supply }\end{array}$ & 0.15 \\
\hline
\end{tabular}

Table 2. Analysis and items of attitude, expected outcomes, individual water-use patterns, social standards and conservation practice towards water use

\begin{tabular}{|l|l|l|l|}
\hline Factors & Item & Indicators & Analysis items \\
\hline $\begin{array}{l}\text { Attitudes to water } \\
\text { conservation } \\
\text { (AWC) }\end{array}$ & AWC1 & $\begin{array}{l}\text { Attitude about the } \\
\text { protection of the } \\
\text { environment }\end{array}$ & The natural environment is precious and delicate \\
\cline { 2 - 4 } & AWC2 & $\begin{array}{l}\text { Preoccupations } \\
\text { concerning } \\
\text { environmental } \\
\text { problems }\end{array}$ & $\begin{array}{l}\text { Over the past decade, severe natural catastrophes } \\
\text { were repeated }\end{array}$ \\
\cline { 2 - 4 } & AWC3 & $\begin{array}{l}\text { Human being and } \\
\text { environment }\end{array}$ & $\begin{array}{l}\text { The natural environment is recognized as a 'user' } \\
\text { in water legislation, and humans can change it } \\
\text { with respect to their needs. }\end{array}$ \\
\cline { 2 - 4 } & AWC4 & $\begin{array}{l}\text { Water resource } \\
\text { importance }\end{array}$ & $\begin{array}{l}\text { One of the most significant natural resources is } \\
\text { water }\end{array}$ \\
\cline { 2 - 4 } & AWC5 & $\begin{array}{l}\text { Water conservation } \\
\text { and environment }\end{array}$ & $\begin{array}{l}\text { Curtailment of water use is an important factor } \\
\text { for the protection of environment. }\end{array}$ \\
\cline { 2 - 4 } & AWC6 & $\begin{array}{l}\text { Water preservation and } \\
\text { human being }\end{array}$ & $\begin{array}{l}\text { Good upbringing and culture are the strong } \\
\text { predictor of water-efficient behavior. }\end{array}$ \\
\hline \multirow{2}{*}{$\begin{array}{l}\text { Expected outcomes } \\
\text { (EO) }\end{array}$} & EO1 & $\begin{array}{l}\text { Water conservation } \\
\text { and supply }\end{array}$ & $\begin{array}{l}\text { Making efforts to conserve water is a sure way to } \\
\text { solve the problem of water supply. }\end{array}$ \\
\cline { 2 - 4 } & EO2 & $\begin{array}{l}\text { Water conservation } \\
\text { and scarcity }\end{array}$ & $\begin{array}{l}\text { It is important to constantly conserve water to } \\
\text { avoid water scarcity. }\end{array}$ \\
\cline { 2 - 4 } & EO3 & $\begin{array}{l}\text { Water conservation } \\
\text { and bills }\end{array}$ & $\begin{array}{l}\text { To save money on water bill, it is necessary to } \\
\text { makes effort to conserve water. }\end{array}$ \\
\cline { 2 - 4 } & EO4 & $\begin{array}{l}\text { Water conservation } \\
\text { and environment }\end{array}$ & $\begin{array}{l}\text { Water conservation represents important pro- } \\
\text { environmental behavior for a sustainable way of } \\
\text { life. }\end{array}$ \\
\hline
\end{tabular}




\begin{tabular}{|c|c|c|c|}
\hline Factors & Item & Indicators & Analysis items \\
\hline \multirow[t]{2}{*}{$\begin{array}{l}\text { Individual water-use } \\
\text { patterns (WUP) }\end{array}$} & WUP1 & $\begin{array}{l}\text { Perceptions of } \\
\text { quotidian activitie } \\
\text { change }\end{array}$ & $\begin{array}{l}\text { Saving water won't change my quotidian } \\
\text { activities. }\end{array}$ \\
\hline & WUP2 & $\begin{array}{l}\text { Perceptions of time } \\
\text { and physical energy } \\
\text { provided }\end{array}$ & $\begin{array}{l}\text { Efficient use of water (i.e. saving water) will not } \\
\text { lead to extra time and physical energy. }\end{array}$ \\
\hline \multirow[t]{2}{*}{$\begin{array}{l}\text { Social standards } \\
\text { (SS) }\end{array}$} & SS1 & $\begin{array}{l}\text { Perception of public } \\
\text { behavior }\end{array}$ & $\begin{array}{l}\text { Inhabitants of my commune practice water } \\
\text { conservation (water saving) }\end{array}$ \\
\hline & SS2 & $\begin{array}{l}\text { Perception of } \\
\text { institution behavior }\end{array}$ & $\begin{array}{l}\text { Water saving practices are among the priority } \\
\text { issues at present time throughout society. }\end{array}$ \\
\hline \multirow[t]{11}{*}{$\begin{array}{l}\text { practices of water } \\
\text { conservation (PWC) }\end{array}$} & PWC1 & Personal hygiene & $\begin{array}{l}\text { Use minimal water for brushing teeth or washing } \\
\text { hands }\end{array}$ \\
\hline & PWC2 & Showering & Take shorter showers \\
\hline & PWC3 & Laundering & Use minimal water where possible for laundering \\
\hline & PWC4 & & $\begin{array}{l}\text { It is desirable to wash many items at the same } \\
\text { time and use the rinse water of a set of items as } \\
\text { wash water for the next. }\end{array}$ \\
\hline & PWC5 & Kitchen & $\begin{array}{l}\text { Do not use running water to wash fruits and } \\
\text { vegetables; rather wash them in a basin }\end{array}$ \\
\hline & PWC6 & & $\begin{array}{l}\text { All kitchen utensils must be washed together in a } \\
\text { basin }\end{array}$ \\
\hline & PWC7 & & $\begin{array}{l}\text { Use a duster cloth to rinse the kitchen utensils } \\
\text { (dishes) in order to avert useless rinsing with } \\
\text { water }\end{array}$ \\
\hline & PWC8 & Home yard cleaning & Sweeping the yards rather than using a hose \\
\hline & PWC9 & & $\begin{array}{l}\text { It's unnecessary to use water to clean yards, but } \\
\text { necessary use minimal water for cleaning toilets }\end{array}$ \\
\hline & PWC10 & $\begin{array}{l}\text { Watering vegetable } \\
\text { garden }\end{array}$ & $\begin{array}{l}\text { Watering vegetable garden just before the sunrise } \\
\text { or after sunset }\end{array}$ \\
\hline & PWC11 & & Reduce strictly watering the vegetable garden. \\
\hline
\end{tabular}

\subsection{Data analysis}

Statistical analyses were performed using SPSS software version 21.0 after coding data from 467 completed questionnaires. A Cronbach's $\alpha$ test was used to evaluate the inner consistency of the quiz items. According to Yan et al. (2016), $\alpha>0.7$ denoted suitable inner consistency. However, the groups AWC, EO, WUP, SS, and PWC possessed $\alpha$ values of $0.819,0.841,0.898,0.862,0.811$ respectively. The characteristics, attitudes to water conservation, expected outcomes, individual water-use patterns, and social standards were compared with practices of water conservation between gender (male and female). Due to the non-normal distribution of the data, Kolmogorov-Smirnov (KS) test was applied to evaluate normality. One-way analysis of variance (ANOVA) followed by post-hoc LSD tests was used to compare average values, using a $5 \%$ significance level $(p<0.05)$.

\section{Results}

\subsection{Social-economic characteristics of the surveyed people}

Statistical analysis of the demographic data was done and presented in Table 3. Investigations were carried in 467 households, i.e. 467 residents including 272 females and 195 males in the commune of Pelengana. Results show that the larger part of households chief was male $(1.33 \pm 0.37)$. The annual revenue average of the respondents was USD $1489.18 \pm 492.68$ and the average household size was $5.07 \pm 0.95$ people per household. The female respondents were less aged $(39.89 \pm 9.07$ years $)$ than male respondents $(42.21 \pm 10.05$ years $)$ and also had a low education ( $4.05 \pm 0.97$ years) compared to the males. 
Table 3. Social-economic characteristics of the surveyed people (average \pm SD)

\begin{tabular}{|l|l|l|l|l|}
\hline \multirow{2}{*}{$\begin{array}{l}\text { Sociodemographic } \\
\text { Profile }\end{array}$} & \multicolumn{2}{|l|}{ Gender of surveyed people } & Average & \multirow{2}{*}{ Significance } \\
\cline { 2 - 4 } & Male $(\mathrm{n}=195)$ & Female $(\mathrm{n}=272)$ & & \\
\hline $\begin{array}{l}\text { Gender of the } \\
\text { household chief }\end{array}$ & $1.33 \pm 0.37$ & $1.12 \pm 0.24$ & $1.23 \pm 0.31$ & 0.580 \\
\hline Age/year & $42.21 \pm 10.05$ & $39.89 \pm 9.07$ & $41.05 \pm 9.56$ & 0.000 \\
\hline Education/year & $5.17 \pm 1.27$ & $4.05 \pm 0.97$ & $4.61 \pm 1.12$ & 0.000 \\
\hline $\begin{array}{l}\text { Household revenue/year } \\
\text { (USD) }\end{array}$ & $1536.07 \pm 501.54$ & $1442.28 \pm 483.81$ & $1489.18 \pm 492.68$ & 0.027 \\
\hline Household size & $4.89 \pm 0.87$ & $5.25 \pm 1.03$ & $5.07 \pm 0.95$ & 0.896 \\
\hline
\end{tabular}

3.2 Water consumption and conservation practices of the surveyed people

The distribution of daily water among the genders towards various tasks is shown in Figure 2. Results showed that the amount of water consumption for women was more twice greater (90.17 Liters per capita day) (Lpcd) than for men (42.43 Lpcd), especially for agricultural tasks (vegetable and garden watering) $(23.87 \pm 8.74 \mathrm{Lpcd})$, kitchen use $(14.10 \pm 4.82 \mathrm{Lpcd})$, laundry $(12.50 \pm 4.57 \mathrm{Lpcd})$, and drinking and personal hygiene $(11.40 \pm 2.39 \mathrm{Lpcd})$. Regarding other activities including home yard cleaning, showering, and livestock, women respondents evenly used more water compared to the men responders.

The practices of water conservation (PWC) considered by respondents during water use include personal hygiene (1 practice), showering (1 practice), laundering (1 practice), kitchen (1 practice), home yard cleaning (1 practice) and watering vegetable garden (1 practice). The amount of PWC performed by the female users outnumbers male users, particularly in using minimal water for brushing teeth or washing hands (PWC1), taking shorter showers (PWC2), by not using running water to wash fruits and vegetables (PWC5), using a duster cloth to rinse the kitchen utensils (PWC7), sweeping the yards rather than using a hose (PWC8), using minimal water for cleaning toilets (PWC9), and watering vegetable garden just before the sunrise or after sunset (PWC10) (Table 4).

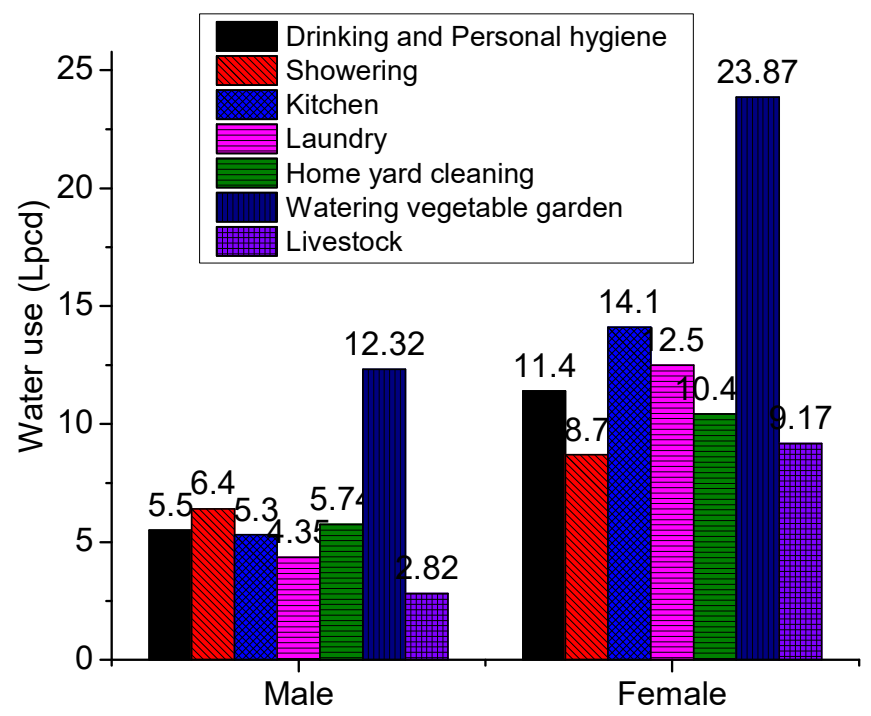

Figure 2. Average water consumption for household use by male and female 
Table 4. Analysis of water conservation practices for male and female

\begin{tabular}{|c|c|c|c|c|c|c|}
\hline \multirow[t]{2}{*}{ Patterns } & \multirow[t]{2}{*}{ Item } & \multirow[t]{2}{*}{ Analysis items } & \multicolumn{2}{|l|}{ Gender } & \multirow[t]{2}{*}{ Average } & \multirow[t]{2}{*}{ Significance } \\
\hline & & & $\begin{array}{l}\text { Male }(n= \\
195)\end{array}$ & $\begin{array}{l}\text { Female }(n= \\
272)\end{array}$ & & \\
\hline $\begin{array}{l}\text { Personal } \\
\text { hygiene }\end{array}$ & PWC1 & $\begin{array}{l}\text { Use minimal water for } \\
\text { brushing teeth or } \\
\text { washing hands }\end{array}$ & $\begin{array}{l}3.91 \pm \\
1.42\end{array}$ & $4.43 \pm 1.01$ & $4.17 \pm 1.22$ & 0.000 \\
\hline Showering & PWC2 & Take shorter showers & $\begin{array}{l}3.82 \pm \\
1.26 \\
\end{array}$ & $4.11 \pm 1.08$ & $3.97 \pm 1.17$ & 0.005 \\
\hline \multirow[t]{2}{*}{ Laundering } & PWC3 & $\begin{array}{l}\text { Use minimal water } \\
\text { where possible for } \\
\text { laundering }\end{array}$ & $\begin{array}{l}4.34 \pm \\
1.09\end{array}$ & $4.35 \pm 1.12$ & $435 \pm 1.11$ & 0.877 \\
\hline & PWC4 & $\begin{array}{l}\text { It is desirable to wash } \\
\text { many items at the same } \\
\text { time and use the rinse } \\
\text { water of a set of items as } \\
\text { wash water for the next }\end{array}$ & $4.52 \pm 086$ & $4.45 \pm 0.81$ & $4.49 \pm 0.84$ & 0.586 \\
\hline \multirow[t]{3}{*}{ Kitchen } & PWC5 & $\begin{array}{l}\text { Do not use running } \\
\text { water to wash fruits and } \\
\text { vegetables; rather wash } \\
\text { them in a basin }\end{array}$ & $3.21 \pm 1.25$ & $4.05 \pm 1.63$ & $3.63 \pm 1.44$ & 0.000 \\
\hline & PWC6 & $\begin{array}{l}\text { All kitchen utensils must } \\
\text { be washed together in a } \\
\text { basin }\end{array}$ & $3.79 \pm 1.38$ & $4.00 \pm 1.41$ & $3.90 \pm 1.40$ & 0.762 \\
\hline & PWC7 & $\begin{array}{l}\text { Use a duster cloth to } \\
\text { rinse the kitchen utensils } \\
\text { (dishes) in order to avert } \\
\text { useless rinsing with } \\
\text { water }\end{array}$ & $3.31 \pm 1.60$ & $3.89 \pm 1.62$ & $3.60 \pm 1.61$ & 0.000 \\
\hline \multirow[t]{2}{*}{$\begin{array}{l}\text { Home yard } \\
\text { cleaning }\end{array}$} & PWC8 & $\begin{array}{l}\text { Sweeping the yards } \\
\text { rather than using a hose }\end{array}$ & $3.69 \pm 1.50$ & $4.02 \pm 1.43$ & $3.86 \pm 1.47$ & 0.000 \\
\hline & PWC9 & $\begin{array}{l}\text { It's unnecessary to use } \\
\text { water to clean yards, but } \\
\text { necessary use minimal } \\
\text { water for cleaning toilets }\end{array}$ & $4.10 \pm 1.02$ & $4.28 \pm 1.15$ & $4.19 \pm 1.09$ & 0.022 \\
\hline \multirow[t]{2}{*}{$\begin{array}{l}\text { Watering } \\
\text { vegetable } \\
\text { garden } \\
\end{array}$} & PWC10 & $\begin{array}{l}\text { Watering vegetable } \\
\text { garden just before the } \\
\text { sunrise or after sunset }\end{array}$ & $4.48 \pm 0.85$ & $4.59 \pm 0.78$ & $4.54 \pm 0.82$ & 0.210 \\
\hline & PWC11 & $\begin{array}{l}\text { Reduce strictly watering } \\
\text { the vegetable garden }\end{array}$ & $3.63 \pm 1.20$ & $3.62 \pm 1.22$ & $3.63 \pm 1.21$ & 0.983 \\
\hline Cronbach's $\alpha$ & 0.811 & & & & & \\
\hline
\end{tabular}

3.3 Attitude, expected outcomes, individual water-use patterns and social standards between male and female Overall, participants had a positive (good) awareness towards environmental protection et comparatively weaker awareness towards water conservation (Table 5). They were seriously concerned about the environmental problems that they were facing and had a good understanding of environmental protection and use. However, they did not understand the correlation between water preservation and the environment, and also between water conservation and human being. Results show that men users detained more knowledge and a positive attitude towards conservation compared to the women users, especially as regards environmental problems and protection (AWC1 and $\mathrm{AWC} 2$ ), the link between water conservation and environment, and also between water conservation and human being (AWC5 and AWC6).

The participants stated that water conservation translates to a relative reduction in water bills (EO3) and mitigate water scarcity (EO2). Women users used water conservation in order to save water costs (EO3), while men users practiced it principally to mitigate water supply scarcity (EO2). The both male and female doubted that PWC could have a significant impact on the environment (EO4). The primary obstacles to the practice of water conservation were daily activities changes (WUP1) and the necessity for extra time and physical energy provided (WUP2), especially for men users. An overwhelming majority of the participants, mainly men, felt that the public and water institutions were not actively engaged in water conservation campaigns. 
Table 5. Evaluations of attitude, expected outcomes, Individual water-use patterns, and social standards about water conservation practice

\begin{tabular}{|c|c|c|c|c|c|c|}
\hline \multirow[t]{2}{*}{ Factors } & \multirow[t]{2}{*}{ Item } & \multirow[t]{2}{*}{ Indicators } & \multicolumn{2}{|l|}{ Gender } & \multirow[t]{2}{*}{ Average } & \multirow[t]{2}{*}{ Significance } \\
\hline & & & Male $(n=195)$ & $\begin{array}{l}\text { Female } \\
(\mathrm{n}=272)\end{array}$ & & \\
\hline \multirow{6}{*}{$\begin{array}{l}\text { Attitudes to } \\
\text { water } \\
\text { conservation } \\
\text { (AWC) }\end{array}$} & AWC1 & $\begin{array}{l}\text { Attitude about the } \\
\text { protection of the } \\
\text { environment }\end{array}$ & $4.18 \pm 1.27$ & $3.46 \pm 0.94$ & $3.82 \pm 1.11$ & 0.000 \\
\hline & AWC2 & $\begin{array}{l}\text { Preoccupations } \\
\text { concerning } \\
\text { environmental problems }\end{array}$ & $4.39 \pm 1.52$ & $3.89 \pm 0.87$ & $4.14 \pm 1.20$ & 0.000 \\
\hline & AWC3 & $\begin{array}{l}\text { Human being and } \\
\text { environment }\end{array}$ & $3.96 \pm 0.86$ & $3.95 \pm 0.85$ & $3.96 \pm 0.86$ & 0.897 \\
\hline & AWC4 & $\begin{array}{l}\text { Water resource } \\
\text { importance }\end{array}$ & $3.98 \pm 1.12$ & $3.92 \pm 1.08$ & $3.95 \pm 1.10$ & 0.541 \\
\hline & AWC5 & $\begin{array}{l}\text { Water conservation and } \\
\text { environment }\end{array}$ & $3.92 \pm 1.32$ & $3.39 \pm 1.21$ & $3.66 \pm 1.27$ & 0.000 \\
\hline & AWC6 & $\begin{array}{l}\text { Water preservation and } \\
\text { human being }\end{array}$ & $3.66 \pm 1.23$ & $3.15 \pm 1.11$ & $3.41 \pm 1.17$ & 0.000 \\
\hline Cronbach's $\alpha$ & & 0.819 & & & & \\
\hline \multirow{4}{*}{$\begin{array}{l}\text { Expected } \\
\text { outcomes } \\
(\mathrm{EO}) \\
\end{array}$} & EO1 & $\begin{array}{l}\text { Water conservation and } \\
\text { supply }\end{array}$ & $3.49 \pm 1.37$ & $3.42 \pm 1.38$ & $3.46 \pm 1.38$ & 0.610 \\
\hline & $\mathrm{EO} 2$ & $\begin{array}{l}\text { Water conservation and } \\
\text { scarcity }\end{array}$ & $3.93 \pm 1.23$ & $3.72 \pm 1.10$ & $3.83 \pm 1.17$ & 0.000 \\
\hline & EO3 & $\begin{array}{l}\text { Water conservation and } \\
\text { bills }\end{array}$ & $3.78 \pm 0.86$ & $4.29 \pm 1.30$ & $4.06 \pm 1.08$ & 0.000 \\
\hline & EO4 & $\begin{array}{l}\text { Water conservation and } \\
\text { environment }\end{array}$ & $2.02 \pm 1.32$ & $2.09 \pm 1.38$ & $2.06 \pm 1.35$ & 0.564 \\
\hline Cronbach's $\alpha$ & & 0.841 & & & & \\
\hline \multirow{2}{*}{$\begin{array}{l}\text { Individual } \\
\text { water-use } \\
\text { patterns } \\
\text { (WUP) } \\
\end{array}$} & WUP1 & $\begin{array}{l}\text { Perceptions of quotidian } \\
\text { activitie change }\end{array}$ & $2.53 \pm 1.01$ & $3.27 \pm 1.09$ & $2.90 \pm 1.05$ & 0.000 \\
\hline & WUP2 & $\begin{array}{l}\text { Perceptions of time and } \\
\text { physical energy provided }\end{array}$ & $2.30 \pm 0.87$ & $3.30 \pm 1.19$ & $2.80 \pm 1.03$ & 0.000 \\
\hline Cronbach's $\alpha$ & & 0.898 & & & & \\
\hline \multirow{2}{*}{$\begin{array}{l}\text { Social } \\
\text { standards } \\
(\mathrm{SS}) \\
\end{array}$} & SS1 & $\begin{array}{l}\text { Perception of public } \\
\text { behavior }\end{array}$ & $3.01 \pm 1.35$ & $3.52 \pm 1.45$ & $3.27 \pm 1.40$ & 0.000 \\
\hline & $\mathrm{SS} 2$ & $\begin{array}{l}\text { Perception of institution } \\
\text { behavior }\end{array}$ & $1.42 \pm 1.61$ & $1.53 \pm 1.57$ & $1.48 \pm 1.59$ & 0.421 \\
\hline Cronbach's $\alpha$ & & 0.862 & & & & \\
\hline
\end{tabular}

\section{Discussion}

In rural Mali, the amount of water consumed by women is more twice that of men. Domestic activities are the main cause of such water consumption by women, as it has been proved in many low-income countries that women are the principal stakeholders in the daily activities of households, namely Algeria (Akli \& Bedrani 2014), Ghana (Akuffo et al., 2013), Cameroon (Tyler et al., 2017), and Nigeria (Oloruntoba et al., 2014). As a result, women's views about the management and conservation of water resources must imperatively be taken into consideration. Interestingly, the notable differences between females and males are there regarding water fetching (Akuffo et al., 2013), water consumption (Yan \& Liangxin 2017), and decision-making and politics (Ariadna 2018). This investigation revealed that there are significant differences between the awareness of water conservation and behavior of men and women. Females have adopted a lot of PWC than males; this conclusion is consistent with other previous studies, which have shown that women practiced more water-saving behavior compared to men (Hablemitoglu et al., 2017). In Mali, women outnumber men in adopting PWC, principally due to severe waterstressed environments, to their lived experiences and souvenir of hard periods of water scarcity. Studies have 
revealed a high correlation between past experience of water scarcity with water awareness and water use behaviors (Graymore et al., 2007).

Gilg et al. (2006) stated that in addition to the adoption of PWC, the education of children, as well as the supervision of family members in the implementation of PWC are also assigned to women. In this work, it has been proved that female participants had a low level of education compared to male participants. In low-income countries, the absence of sufficient education of women is a great obstacle to their capacity to ensure adequate education and supervision of children and family members in order to achieve better water conservation (Fan et al., 2013). According to the most recent UNESCO estimates, there are around 796 million illiterate adults in the world, about $64 \%$ of whom are women. Additionally, it is estimated that $38 \%$ of African adults (about 153 million) lack minimal literacy and two-thirds of them are women (UNESCO 2015). As a result, women's education is a factor which needs to be duly considered to ensure effective practices of water conservation by the entire family and society.

Gender is a social variable that allows to differentiate, organize and structure the relationships between actors and actresses social (i.e. between females and males). It refers to the social relations (unequal or not) existing between men and women, in all fields (education, health, access to resources, participation in decision-making bodies) and all levels (individual, family, community, national and international). Thus, a participatory and equitable development of males and females must be promoted, ensuring equal and equitable access and control of resources and decision-making, while respecting their fundamental rights. Nevertheless, public water conservation policies are generally gender-neutral, indicating that gender differences are neglected (Yan \& Liangxin 2017). Our study claimed that factors affecting PWC differ considerably across genders. Women consumers engage in practices of conservation principally because they hope for the positive outcomes about conservation (water bills reduction, water scarcity reduction) and social standards (public perception and decisionmakers' attitudes with regard to practices of water conservation). On the other hand, adoption of practices of water conservation by males depends primarily on their attitude, individual water-use patterns (perceptions of change in their daily activities, time and physical energy provided for water conservation practices), and social standards. Clearness of details with respect to water use by consumers is extremely important for water conservation (Bruns et al., 2015). In this study, it was revealed that this factor is so significant to women consumers compared to men consumers as they are more concerned about the well-being of others. The main reason that women have embraced $\mathrm{PWC}$ is the high cost of purchasing water. Indeed, water price is the principal indicator to consumers of the amount of water they consume (Yan \& Liangxin 2017). However, other studies have claimed that utilization of water bills to promote PWC amongst consumers given discouraging findings in low-income countries (Styles et al., 2015). The diversity of water sources, bad types of equipment and management, and ineffective packages with other bills are the major obstacles to the clearness of prices (Fan et al., 2013).

Social standards refer to socially shared rules or individual patterns of behavior, based on common values and pressure for the adoption of an acceptable behavior (Lapinski \& Rimal 2005). They reflect on individual knowledge of what others must accomplish and of what they believe an individual should perform (Rimal 2005). In this study, it was noticed that such social standards influence the conservation behaviors of both men and women consumers. The findings found in Nancarrow and Syme's (1989) study showed that public policy decisions can affect the public's water conservation behavior. This verifies the findings found in the study conducted by Jorgensen et al. (2009), which confirmed that, whether the public realizes that water management authorities and the remainder of the public are not trustworthy, they will not respect their water conservation recommendations. Therefore, this reflects the close relationship between trust and social standards. Trusted authorities and the public will encourage the effort of the individual to revise their behavior in order to adopt PWC while enhancing the ability to control his/her water-use patterns, which affects behavioral change among males and females. It is therefore essential to strengthen users ' confidence in the public and the authorities in order to bring about a change in behavior. It has been observed by Miao et al. (2013) that users' confidence depends on the information they are provided and, in some cases, on their confidence in those who provide information to them. However, such detail is generally absent, unclear and even self-conflicting due to mismanagement. As a result, translucency of information and circulation of messages between consumers, and authorities are very advantageous in creating networks of confidence in order to improve social standards and the ability to control individual water conservation behavior.

\section{Conclusion}

Ongoing increases of gaps among productive capacities and growing request for water is a serious menace to sustainable suitable drinking water supply and rural development. Inappropriate PWC of inhabitants could be assigned to the perceived poor result of PWC (poor perceptions of reduced water prices, reduction of water scarcity and environmental protection by PWC), poor control individual water-use patterns (unacceptance of daily activities changes and physical energy provided) and absence of social assistance (poor perceptions of the public and decision-makers i.e. the government about PWC), notably absence of account of gender equality and female's 
opinion on PWC. Women consumers engage in practices of conservation principally to reduce water costs, while men consumers adopt PWC principally for water scarcity reduction. Unwillingness to change daily habits and demands of extra time and effort are the principal obstacles to adoption of PWC men consumers, while the absence of social assistance is the principal obstacles to involvement of women consumers in PWC. Community-based strategies in the rural villages of Mali should be envisaged to encourage the PWC of inhabitants, including (1) highlighting gender equality and female's viewpoint while developing public policies that support water conservation; (2) establish a clear water price reform to encourage efficient water conservation by women consumers, and introduce a rebate system being whereby conserving water would be financially rewarded; and (3) enhance information clarity and communication among gender, consumers, and decision-makers to strengthen social assistance for water conservation.

\section{References}

Akli, S., Bedrani, S. (2014), "Gender inequalities in the public water authorities in Algeria". New Medit, 13 (3), 70-80.

Akuffo, I., Cobbina, S.J., Alhassan, E.H., Nkoom, M. (2013), "Assessment Of The Quality Of Water Before And After Storage In The Nyankpala Community Of The Tolon-Kumbungu District, Ghana". INTERNATIONAL JOURNAL OF SCIENTIFIC \& TECHNOLOGY RESEARCH, 2(2), 221-227.

Amadou Toure, D. W. and Z. K. (2018), "An investigation of some water quality properties from different sources in Pelengana commune, Segou, Mali". Journal of Water, Sanitation and Hygiene for Development, 8(3), 449458. https://doi.org/10.2166/washdev.2018.172.

Ariadna Gabarda-Mallorquí, R. M. F. and A. R. (2018), "Exploring Environmental Awareness and Behavior among Guests at Hotels That Apply Water-Saving Measures". Sustainability, 10, 1305; doi:10.3390/su10051305.

Bruns-Smith, A.; Choy, V.; Chong, H.; Verma, R. (2015), "Environmental sustainability in the hospitality industry: Best practices, guest participation, and customer satisfaction". Cornell Hosp. Rep, 15, 6-16.

Caruso, B.A., Sevilimedu, V., Fung, I.C.H., Patkar, A., Baker, K. K. (2015), "Gender disparities in water, sanitation, and global health". Lancet, 386 (9994), 650-651.

Coulibaly, P. M. A. (2009), "Approvisionnement, consommation de l' eau potable et assainissement en commune I du District de Bamako : le cas de Bankoni et de Djélibougou", 1-80.

Fan, L.X., Liu, G.B., Wang, F Geissen, V., Ritsema, C.J., Tong, Y. (2013), "Water use patterns and conservation in households of Wei River Basin, China". Resour. Conserv. Recy, 74, 45-53.

Garcetti, G., Kevany, K. (2013), "Water is key - photo essay". J. Clean. Prod, 60, 216-224.

Gilg, A.; Barr, S. (2006), "Behavioural attitudes towards water saving? Evidence from a study of environmental actions". Ecol. Econ, 57, 400-414.

Graymore, M.L.M. and Wallis, A. M. (2010), "Water savings or water efficiency? Water-use attitudes and behaviour in rural and regional areas". International Journal of Sustainable Development and World Ecology, 17(1), 84-93.

Hablemitoglu, S., Ozmete, E. (2010), "Sustainable water management: a case study on saving behaviour of Turkish women for domestic water usage". Eur. J. Soc. Sci, 12 (3), 447-466.

Head, L. and Muir, P. (2007), "Changing cultures of water in Eastern Australian backyard gardens". Social and Cultural Geography, 8(6), 889-905.

Jessica M. Healy Profitós, Arabi Mouhaman, Seungjun Lee, Rebecca Garabed, Mark Moritz, Barbara Piperata, Joe Tien, M. B. and J. L. (2014), “ Muddying the Waters: A New Area of Concern for Drinking Water Contamination in Cameroon. International Journal of Environmental Research and Public Health, 11, 1245412472.

Jorgensen, B., Graymore, M., O’Toole, K. (2009), "Household water use behavior: an integrated model". J. Environ. Manage, 91, 227-236.

Kumpel, E., Nelson, K. (2013), "Comparing microbial water quality in an intermittent and continuous piped water supply". Water Res, 47 (14), 5176-5188.

Lapinski, M.K., Rimal, R. (2005), "An explication of social norms". Commun. Theor, 15 (2), 127-147.

Liangxin Fan, Fei Wang, Guobin Liu, Xiaomei Yang, and W. Q. (2014), "Public Perception of Water Consumption and Its Effects on Water Conservation Behavior". Water, 6, 1771-1784.

Miao, L.; Wei, W. (2013), "Consumers' pro-environmental behavior and the underlying motivations: A comparison between household and hotel settings". Int. J. Hosp. Manag, 32, 102-112.

Nancarrow, BE \& Syme, G. (1989), "Improving Communication with the Public on Water Industry Policy Issues". Urban Water Research Association of Australia, Perth.

Oloruntoba, E.O.; Folarin, T.B.; Ayede, A. I. (2014), "Hygiene and sanitation risk factors of Diarrhoeal disease among under-five children in Ibadan, Nigeria". Afr. Health Sci, 14, 1001-1011.

OWAS, D. E. et A. (2007), "Projet d'Approvisionnement en Eau Potable et d'Assainissement dans les Regions de 
Gao, de Koulikoro et de Segou". Fonds Africain de Developpement, 54.p.

Programme United N. D. (2012), "the Millennium Development Goals Report 2012. United Nations development programme, New York, United States of America". Available at: www.undp.org/content/dam/undp/ library/MDG/english/The_MDG_Report_2012.pdf.

RGPH. (2009), 4 ème Recensement General de la Population et de l'Habitat du Mali ( RGPH-2009) Analyse des resultats definitifs Theme 2 .

RIMAL, R. N., M. K. L. R. J. C. et K. R. (2005), "Moving toward a theory of normative influences". Journal of Health Communication, 10, 433-450.

Shove, E., Franceys, R., Morris, J. (2010), "Behavioural change and water efficiency. In: ESRC (Economic and Social Research Council) Seminar Series e Mapping the Public Landscape". ESRC press, Swindon, United Kingdom.

Styles, D.; Schoenberger, H.; Galvez-Martos, J. (2015), "Water management in the European hospitality sector: Best practice, performance benchmarks and improvement potential". Tour. Manag, 46, 187-202.

Tyler J. Gorham, Joshua Yoo, Rebecca Garabed, A. M. and J. L. (2017), "Water Access, Sanitation, and Hygiene Conditions and Health Outcomes among Two Settlement Types in Rural Far North Cameroon". Int. J. Environ. Res. Public Health, 14(4), 441. doi: 10.3390/ijerph14040441.

UN-WATER/WWAP. (2016), "Rapport national sur la mise en valeur des ressources en eau : Mali". Direction National de l'Hydraulique.

UNESCO (United Nations Educational, S. and C. O. (2015), "EFA GlobalMonitoringReport: Education forAllliteracy for Life". Paris, France.Available at: unesdoc.unesco.org/images/0014/001416/141639e.pdf (accessed 18.08.28)., Upadhyay, B., 2014. Gendered livelihoods and multi.

WHO/UNICEF Joint Monitoring Program. (2015), "Estimates on the Use of Water Sources and Sanitations Facilities". WHO/UNICEF Joint Monitoring Program: Mali, West Africa.

WHO \& UNICEF. (2017), "WHO/UNICEF Joint Monitoring Programme (JMP) for Water Supply and Sanitation". [Online] Available from: www.who.int/water_sanitation_health/publications/jmp-2017/en/.

Yan Tong, Liangxin Fan, H. N. (2017), "Water conservation awareness and practices in households receiving improved water supply: A gender-based analysis". Journal of Cleaner Production, 141, 947-955. 